\title{
Socialització, etnicitat i multiculturalitat a l'escola: reflexions sobre l'alumnat immigrant i gitano i el rol de la llengua a l'entorn educatiu català
}

Socialization, Ethnicity and Multiculturality in the School: Think about the Inmigrant and Gypsy Student Body and the Role of the Language in the Educational Catalan Environment

Facultat de Psicologia de la Pontifícia Universidade Cátólica do Rio Grande do Sul (Brasil)

\section{Resum}

Aquest article reflexiona el model educatiu català i les implicacions del model de relacions amb la diversitat cultural a l'entorn educatiu, sobretot als àmbits de la socialització i l'ús de la llengua catalana, com a marcadors identitaris simbòlics rellevants. A més d'això, es reflexiona sobre els grups minoritaris a l'entorn educatiu català, en especial els alumnes d'origen no comunitari i d'origen gitano i les seves relacions amb la comunitat d'acollida.

Paraules clau: diversitat, escola, immigració

\begin{abstract}
This article reflects on the Catalan educational model and the implications of this model on the relations with the cultural diversity on the educational environment, especially on the socialisation and the use of the Catalan language, as relevant symbolic identity markers. On top of that, it reflects on the minority groups on the Catalan educational system, specially about the students of immigrant backgrounds and from Gipsy origin, and their social relations with the hostess community.
\end{abstract}

Keywords: diversity, school, immigration

\section{Introducció}

\section{Educació $i$ diversitat cultural}

Encara que no hagi estat un fenomen nou en el món, no va ser fins als anys seixanta i setanta del segle $\mathrm{xx}$, que alguns educadors nord-americans van suggerir que 
alumnes de grups minoritaris presentaven dificultats escolars perquè no s'havien adaptat de forma consistent, o assimilat, «l'american way of life». Encara que sigui un avenç entendre que hi hagi altres aspectes no només estrictament «cognitius» en el procés de desenvolupament de l'aprenentatge, un cop més es crea una segona jerarquia: la cultural. Hi ha cultures més desenvolupades o més adaptatives que altres, tot i que es concebi la cultura d'una manera molt positivista.

Això ha generat una idea de «discapacitat» cultural, o sigui «minusvalia» cultural, que fa que alumnes d'orígens culturals i ètnics minoritaris siguin entesos com a portadors d'una potencial dificultat addicional en el seu procés d'aprenentatge, que sempre ha estat molt marcat pels referents cultural majoritaris de cada lloc (Woolfolk, 2000).

La perspectiva que va suplantar la del dèficit cultural és la de l'educació multicultural, on s'entén que l'escola és de tots els alumnes, independentment dels grups als que pertanyin. Aquests grups es defineixen amb relació al gènere, ètnia, raça, cultura, classe social, religió, o excepcionalitat, i es troben amb igualtat de drets de viure el procés escolar (Gadotti, 1993; Woolfolk, 2000). Això és la teoria, encara que es pot qüestionar si en alguna part del món s’ha aplicat de forma efectiva.

És clar que la institució escolar respira i transmet una cultura que, en general, fa referència a la cultura de la societat en què es troba i respon a les necessitats del grup majoritari (Sandín, 2002: 37-46). Tot i així, per als alumnes pertanyents a grups culturals minoritaris, la cultura escolar pot significar un llast, un mur que dificulti els seus processos adaptatius o d'integració.

Els professors transmeten implícitament als alumnes les seves actituds i preferències per la forma com organitzen les seves classes. Diversos estudis empírics analitzats per Lubart (2007) assenyalen que els professors poden tenir una concepció particular de l'alumne ideal, valorant l'obediència i el conformisme; en detriment de traços com la curiositat o la independència. L'alumne ideal, per a bona part dels mestres del món, és freqüentment un nen que segueix les instruccions, que treballa de manera silenciosa i fa preguntes de comprensió o de precisió sobre les matèries ensenyades.

La institució que ha estat objecte de més atenció, quant a canalitzadora del desenvolupament (almenys cognitiu), ha estat l'escola formal. Totes les societats s'asseguren, de diferents maneres, que els joves arribin a estar preparats en un moment donat per a prendre part de les destreses madures de la cultura; tot i així, els mitjans que utilitzen perquè els individus arribin a integrar-se en la cultura, i el tipus d'instrucció, varien des de la participació pròxima en contextos pràctics, fins a l'aprenentatge formal, i tot això pot estar acompanyat per la pràctica de determinats ritus en períodes de transició i formes molt variades d'escolarització (Rogoff, 1993).

Actualment, les investigacions sobre les contribucions de l'escola al desenvolupament de competències per a relacions interpersonals (com ara les eines culturals, comunicatives, pautes i normes socials, etc.) estan fragmentades en diferents contex- 
tos teòrics. Precisament, les múltiples dimensions de l'experiència que l'escola proporciona als nens dificulten la determinació dels efectes i les influències que aquesta té en el seu desenvolupament (Crespo i altres, 1994: 134-156). Tot i això, és lògic suposar que aquests efectes són rellevants, atenent al pes temporal i d'experiència en la vida del nen que passa per un procés d'escolarització, sobretot en nens i nenes d'entorns culturals minoritaris, que tenen l'escola com l'única porta d'entrada a la societat «formal» de la cultura del grup majoritari.

Segons Sandín (2002: 37-46), els nens i les nenes de la població majoritària adquireixen el llenguatge, els costums i les pautes culturals, d'una manera «natural $\mathrm{i}$ inconscient» a través dels processos d'enculturació no explícits. En canvi, per a l'alumnat dels grups minoritaris, aquest fenomen pot convertir-se en un procés d'aculturació (Berry, 2001: III, 615-631) on l'assumpció de regles de la cultura majoritària pot coexistir amb les seues d'origen, així com substituir-lo o modificar-lo, deixant més explícit el seu caràcter sociohistòric. Moltes vegades aquests alumnes no estan familiaritzats amb l'estructura escolar de la cultura majoritària, les expectatives del seu professorat i dels procediments d'aula. Els objectius educatius no es limiten als objectius instruccionals, sinó que també inclouen l'enculturació o la socialització de l'alumnat en alguns valors o expectatives (Sandín, 2002: 37-46).

La preocupació pels sistemes d'ensenyament, educació i salut comunitària, així com la preocupació dels investigadors d'aquestes àrees, pels diferents grups socials, ètnics $i$ culturals que componen la societat es manifesten, en conseqüència, amb pressions contundents, denúncies i reivindicacions de grups empesos al marge de la societat, subestimats, no respectats i, moltes vegades, deshumanitzats.

\section{L'educació multicultural}

A l'Europa d'avui, el multiculturalisme passa a ser un «problema» per a l'educació quan augmenta el número de fills d'immigrants, vinguts predominantment d'Àfrica i Àsia (McLaren, 1995). Segons Greenfield i Cocking (1994) l'experiència nordamericana amb la integració de grups minoritaris (afroamericans, natius, immigrants estrangers de països pobres) posa de manifest la importància d'entendre el desenvolupament i l'escolarització de nens i nenes de grups minoritaris en relació amb les dinàmiques d'inclusió i exclusió viscudes entre la societat majoritària i les minories, a més de la continuitat o el xoc de valors i metes educatives entre ambdós grups.

L'educació multicultural és una demanda social i els objectius d'aquesta busquen la superació de desigualtats i la construcció d'un món cultural i ètnicament divers. Per tant, ha de comptar amb els professors, els orientadors, els psicòlegs escolars, els alumnes i els pares. Un altre objectiu és el de «reformar» les escoles $\mathrm{i}$ altres institucions educatives, de tal manera que els estudiants oriünds de diferents grups racials, 
ètnics i de classe social, puguin experimentar la igualtat educativa. Això dóna lloc a una de les metes prioritàries en aquesta direcció, que és la d'afavorir els alumnes a adquirir coneixements, actituds i habilitats necessàries perquè participin d'una societat plural i democràtica i interaccionin i es comuniquin amb persones de diferents grups, a fi de crear una comunitat orientada vers la igualtat (Gadotti, 1993; Silva, 1998: 381-398).

Segons Essomba (2002: 11-14) l'educació per la diversitat cultural, tot i ser molt diversa en les seves múltiples experiències, es pot entendre a través de tres funcions bàsiques: la transformadora (entesa com interdepenent dels sistemes educatius i de més sistemes socials en consens); el control del procés (a través de la retroalimentació i de la flexibilitat), i la funció prospectiva (avaluació que permet establir nous objectius per la realitat que es pretén construir).

Encara que la pluralitat o la diversitat d'origen cultural de l'alumnat no sigui una realitat desitjada en tots els entorns nacionals o polítics (per exemple en la realitat catalana o espanyola -OSPDH, 2006), és una realitat que existeix. I cada cop existeix més. Segons dades del Departament d'Educació de la Generalitat de Catalunya (2005), el nombre total d'alumnes estrangers ha experimentat un increment considerable en els últims deu anys: al curs 1991-1992 hi havia 9.868 alumnes d'origen estranger sobre una població escolar total -ensenyament obligatori i postobligatori- d'1.218.879 i al 2003-2004, n’hi ha 74.491 sobre un total de 974.381, com es pot veure en el gràfic 1.

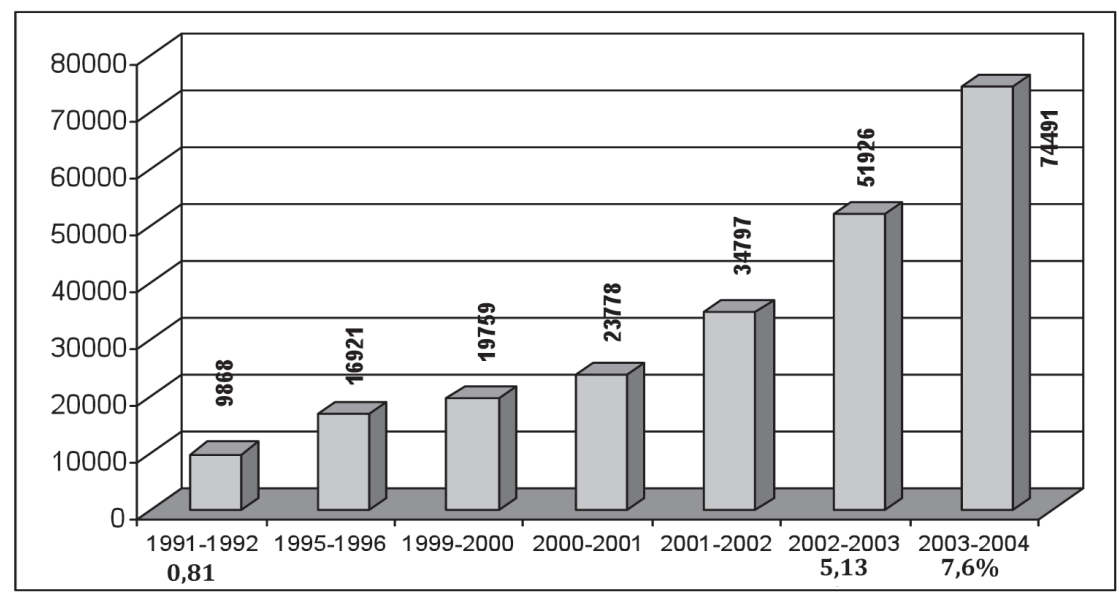

Gràfic 1: Nombre total d'alumnes estrangers en el sistema educatiu català de 1991 a 2004.

Atesa la disminució de la població escolar global i malgrat les xifres absolutes, el percentatge s'ha multiplicat per nou (ha passat del 0,81\% al 7,6\% global). Evidentment, ni el sistema educatiu, ni el sistema social global estaven preparats per a un 
increment tan significatiu de la diversitat en la realitat cultural a Catalunya. I encara s'hauria de considerar un altre element important a afegir al complex panorama: les poques ganes d'augmentar els elements de diversitat cultural i la preocupació per mantenir un eix de conservació d'uns elements atribuïts com a centrals d'una identitat catalana -percebuda com «tradicional» o «de tota la vida» (OSPDH, 2006).

Tot $i$ que en xifres globals el percentatge encara és baix comparat amb altres països europeus, si el flux immigratori continua amb el mateix ritme que en els últims anys, el curs 2005-2006 es podria assolir un percentatge proper al 10\% en totes les etapes, que s'acostaria a la mitjana europea i aniria creixent en els propers cursos (Generalitat de Catalunya, 2005).

Evidentment, encara que en contra de les preocupacions «tradicionals» (la promoció de la identitat catalana a través, sobretot, de programes d'immersió lingǘstica) del sistema educatiu català, el Departament d'Educació de la Generalitat de Catalunya ha desenvolupat una sèrie de programes i plans d'acció per a atendre aquesta realitat mutant (Generalitat de Catalunya, 2005). S'han canviat part de les perspectives, sobretot les que es refereixen a l'ús del català com a llengua escolar i del paper que la llengua juga en els entorns educatius. Segons la postura oficial del Departament d'Educació, a través del Pla per a la Llengua i la Cohesió Social:

Els centres docents han d'assumir l'acollida i la integració de l'alumnat de nacionalitat estrangera de nova incorporació al sistema educatiu com una tasca bàsica $\mathrm{i}$ fonamental. Aquesta és una nova exigència educativa $\mathrm{i}$ social comuna a tots els països que formen part de l'Europa del benestar. Així mateix, els centres han de posar en marxa estratègies pedagògiques que atenguin les necessitats específiques d'aquell alumnat amb risc de marginació. Cal que l'escola converteixi aquests reptes en una oportunitat de millora de tot el sistema, que respecti la diversitat i que garanteixi la igualtat de totes les persones (Generalitat de Catalunya, 2000: 4).

Encara que compost per paraules clarament inmerses dins d'un marc multicultural, les paraules no sempre es troben reflectides en la vida quotidiana de les escoles, i molts cops s'allunyen molt d'aquesta perspectiva, segons il-lustra una porció d'estudis en l'àrea (Carrasco, 2004a, 2004b: 205-231; Essomba, 2003; Jordán, 1994; Lalueza i Crespo, 1996: 51-69; San Román, 1996). Aquesta contradicció es veu reflectida també en el pla d'acció desenvolupat pel Departament d'Educació que, a la seva pàgina 3 , quan justifica que la llengua és l'element identitari més important de la societat catalana, també afirma que encara existeixen moltes «amenaces latents» que: «En l'actual context social es fa més evident encara l'enorme fragilitat de la llengua catalana». L'únic canvi social anomenat en el pla és l'increment de la immigració, és a dir, és l'element «oficialment» més amenaçador de la llengua i, en conseqüència, de la identitat i, per tant, de «l'existència» de Catalunya. 
Per més fatalista (i exagerada) que sigui aquesta anàlisi, connecta molt amb la percepció de bona part de la població local (OSPDH, 2006). Però com assenyalen Hagendoorn i altres (1998: IV, 483-503), ni tots els diferents són igualment diferents. N'hi ha de més diferents i de més amenaçadors que altres. Segons Snellman i Ekehammar (2005: 83-94) i Hagendoorn i altres (1998: IV, 483-503), les societats d'acollida (aquí parlem d'investigacions en diferents països europeus) perceben com a més allunyades i menys desitjables les persones pertanyents als grups culturals que identifiquen més allunyats dels seus. Aquesta distància en molts casos és directament influïda per aspectes històrics, simbòlics, ètnics i geogràfics compartits. Encara que no s'hagi trobat cap investigació que il.lustri de manera directa com identifiquen els grups ètnics minoritaris a Catalunya la seva població «utòctona» hi ha dades que poden donar una idea de com succeeix aquesta valoració i quina és la realitat concreta amb què es troba la societat.

La graella 1 il.lustra la diversitat de l'alumnat estranger a Catalunya en el curs 2003-2004 (Generalitat de Catalunya, 2005).

\begin{tabular}{|c|c|c|c|c|c|}
\hline \multirow[b]{2}{*}{ Curs 2003-2004 } & Ed. infantil & Ed. primària & $\mathrm{ESO}$ & \multirow{2}{*}{$\begin{array}{c}\text { Total } \\
\text { alumnat } \\
\text { estranger }\end{array}$} & \multirow{2}{*}{\begin{tabular}{|c|c|}
$\begin{array}{c}\text { global sobre } \\
\text { l'alumnat } \\
\text { estranger }\end{array}$ \\
\end{tabular}} \\
\hline & $\begin{array}{l}\text { Alumnat } \\
\text { estranger }\end{array}$ & $\begin{array}{l}\text { Alumnat } \\
\text { estranger }\end{array}$ & $\begin{array}{l}\text { Alumnat } \\
\text { estranger }\end{array}$ & & \\
\hline Resta Unió Europea & 911 & 1.834 & 1.048 & 3.793 & $5,6 \%$ \\
\hline Resta d'Europa & 1.234 & 2.872 & 1.929 & 6.035 & $8,9 \%$ \\
\hline Magrib & 4.735 & 8.768 & 5.607 & 19.110 & $28,1 \%$ \\
\hline Resta d'Àfrica & 1.045 & 1.399 & 442 & 2.886 & $4,2 \%$ \\
\hline Amèrica del Nord & 73 & 162 & 84 & 319 & $0,5 \%$ \\
\hline $\begin{array}{l}\text { Amèrica Central i del } \\
\text { Sud }\end{array}$ & 6.308 & 15.978 & 9.673 & 31.959 & $46,9 \%$ \\
\hline Àsia i Oceania & 782 & 1.747 & 1.484 & 4.013 & $5,9 \%$ \\
\hline Total alumnat estranger & 15.088 & 32.760 & 20.267 & 68.115 & $8.4 \%$ \\
\hline Total alumnes & 187.368 & 362.872 & 257.031 & 807.271 & \\
\hline
\end{tabular}

Graella 1: Número d'alumnes estrangers en el curs 2003-2004 en Catalunya, segons l'origen.

Aquestes dades, a més d'il.lustrar el número de «diferents», il.lustra la pluralitat que pot tenir aquesta diferència. El pla elaborat pel Departament d'Educació també il.lustra que el nombre d'alumnes de cada procedència ha sofert grans variacions; mentre alguns collectius han crescut poc, el grup procedent de l'Europa no comunitària s'ha multiplicat per set i el procedent de l'Amèrica, Central i del Sud, que en el curs 2001-2002 ja havia superat lleugerament el del Magrib -que era el més nombrós-, en l'actual l'ha superat significativament (ha passat de 4.188 alumnes en el curs 1999-2000 a 31.959 en el curs 2003-2004).

Però entendre com valora la població aquesta realitat en el món escolar català no és fàcil i, inevitablement, es caurà en certs reduccionismes. Tot i així, hi ha investigacions que poden aportar elements que collaborin en l'enteniment de com aquesta realitat plural creixent en les escoles (i en les altres esferes públiques) catalanes 
afecta la valoració que la societat fa de la diversitat cultural. Les dades de l'informe: «Imagen mediática y opinión pública sobre la inmigración en España y Catalunya» -Centre de Recerca Observatori del Sistema Penal i Drets Humans Universitat de Barcelona (OSPDH, 2006) - illlustren com l'opinió pública distingeix molt clarament entre «estrangers» els advinguts de l'Europa comunitària, i «immigrants» les persones advingudes d'altres parts del món, sobretot de països entesos amb menys possibilitats econòmiques que Espanya o Catalunya.

Evidentment, això es reflecteix en l'entorn educatiu o es relaciona amb el que s'hi viu. Però hi ha un grup més clarament identificat i que, fins i tot, pot ser entès com a culturalment més llunyà que molts grups d'immigrants dins de l'escola: aquests, evidentment, són els gitanos.

Però aquestes diferències no són d'ara. Encara que no puguin ser entesos com «catalans de tota la vida» dins de l'accepció de l'expresident Jordi Pujol, segons alguns estudis (San Román, 1996, Generalitat de Catalunya, 2005b), la presència gitana a Catalunya està registrada per primera vegada en el segle Xv. Tot i així, després de cinc segles, encara és vist com un grup minoritari, amb un intens rebuig dins de la societat espanyola en general. Rebuig encara més important que la major part del grups immigrants, entesos com a «nouvinguts» tot i que sigui la minoria ètnica més important d'Espanya, demogràfica i simbòlicament (Rodríguez-Bailón i MoyaMorales, 2003: II,176-182; Rueda i Navas, 1996: III, 131-149).

Així doncs, si no és una qüestió de temps, deu ser una qüestió del nombre? Segons les dades de referència de la Generalitat de Catalunya, Departament de Benestar i Família (2005b), la població gitana de Catalunya s’apropa als 53.000 integrants, o gairebé 8,4\% de la població general de Catalunya (Generalitat de Catalunya, 2005b, p. 17). Però si fa més de cinc segles que són a Catalunya, i són gairebé el $8,4 \%$ de la població, per què es destaca tant la seva diferència?

Segons moltes teories de la psicologia social (tal com la de la identitat social de Tajfel), la similitud entre els valors pot ser percebuda com a amenaçant per a aquells grups que vegin reduïda la possibilitat d'aconseguir una identitat social distintiva amb relació a certs exogrups (Rodríguez-Bailón i Moya-Morales, 2003: II,176-182). Per tant, si se segueix aquesta perspectiva, és justament la poca diferència «explícita» la que genera la necessitat de creació de marcadors «implícits» que diferencien els espanyols/catalans gitanos dels no gitanos. Si ens apropem més la realitat educativa de la població gitana a Catalunya es pot començar per la postura oficial:

La situació educativa entre la població gitana a Catalunya és complicada i preocupa tant l'Administració pública com famílies i professorat. [...] Les persones gitanes no troben reflectida la seva identitat en forma de currículum, en forma de professorat o en la gestió i l'organització dels centres. No es planteja una educació multicultural adreçada a la diversitat de colllectius (Generalitat de Catalunya, 2005b: 135-136). 
Aquestes afirmacions, presents en l'Estudi sobre la població gitana de Catalunya. Informe final, promogut pel Departament de Benestar i Família de la Generalitat de Catalunya (2005b), donen la idea central del «problema» gitano a l'escola catalana. Encara que representin un 8,4 \% de la població general de Catalunya, la realitat a l'escola, segons la Diputació de Barcelona (2000), és una mica diferent, un cop que reconeixen les dades d'aquesta institució, l'any 2000, a la ciutat de Barcelona, la població gitana en l'Educació Infantil era de l'1,42 \%; en l'Educació Primària, l'1,45\% i el $0.60 \%$ de l'alumnat matriculat en l'Educació Secundària Obligatòria, a la ciutat de Barcelona (Diputació de Barcelona, 2000:189-191). Així doncs, si en la societat general la població gitana es troba rebutjada, a l'escola, el risc d'exclusió sembla ser encara més preocupant.

Parlant de l'ètnia gitana, segurament no podem parlar d'un procés d'aculturació neta $\mathrm{i}$ ràpida en cap sentit. Aquesta minoria ètnica catalana sempre s'ha mostrat molt resistent a la dominació de tota mena, inclosa la cultural. De vegades, aquesta postura també va allunyar encara més les fronteres culturals entre els grups. Aquesta postura de resistència, sumada a la postura d'exclusió i prejudici de la cultura majoritària, van resultar en l'exclusió del contingent gitano de la cultura escolar.

Efectivament, fa poc temps que els nens i les nenes gitanos formen part, de la realitat escolar. Per la seva novetat, en comparació amb els anys d'allunyament, la realitat gitana a l'escola encara és molt experimental. No hi ha un consens en el fet d'apropar-se a les seves necessitats, la valoració de la seva cultura i la comprensió dels seus itineraris educatius i processos propis de construcció del coneixement. El discurs educatiu, moltes vegades, no té correlació amb la pràctica a les aules.

De totes maneres, encara que el professorat evita més o menys acuradament (de bona gana uns i de mala altres) qualsevol al-lusió que pugui considerar-se racista o discriminatòria, l'observació de les classes generen abundants situacions de senyalaments de la seva etnicitat, predominantment vinculada als estereotips més durs (Fernàndez-Enguita, 1999).

Segons el mateix autor, és molt poc probable que un nen o nena gitana passi per l'escola sense que algú atempti contra la seva dignitat. Això no vol dir que l'escola sigui pitjor que altres escenaris socials, però els nens i les nenes són més vulnerables a l'escola. Segurament tenen més probabilitats de topar amb el racisme, la intolerància $\mathrm{i}$ els prejudicis en qualsevol altre entorn, a la seva edat (Fernández-Enguita, 1999). En l'afany d'escolaritzar la població infantil gitana, hi ha el convenciment que, en última instància, la cultura majoritària és superior a la seva i que això seria una accepció reconeguda pels gitanos. Però no s'ho creuen. Ni tampoc creuen els mestres que les diferències culturals del grup gitano (o d'altres minories) mereixen alguna atenció especial, o més adequada a la seva realitat cultural, o fins i tot una atenció personalitzada. 
El més comú no és una afirmació de les excel-lències de la diversificació o la individualització, sinó simplement ignorar les diferències (Fernández-Enguita, 1999) i mantenir «l'equilibri d'abans». Evidentment, la imposició de la presència dels gitanos en el món escolar es veu com un «problema».

Segons San Román i altres (2001), el principal «problema» no és altre que la «monoculturalitat autoritària i dogmàtica» dels diferents signes que impregnen, almenys, un gran nombre d'escoles i centres educatius - en pensaments i actitudsgeneralment difosos i confusos, si no inconscients. Dintre de les «façanes» que la «monoculturalitat autoritària i dogmàtica» a què es refereixen San Román i altres (2001) pot adoptar, el prejudici i els estereotips, l'ús de la llengua catalana a l'escola, així com el discurs del professorat vers la diversitat cultural són dels més importants per l'enteniment de les relacions del món escolar amb la cultura.

Un fenomen observat en moltes societats on hi ha un creixement de la diversitat cultural és el desenvolupament de noves formes d'expressió de prejudicis, estereotips i jerarquització ètnica (Snellman i Ekehammar, 2005: 83-94). El món de l'educació no és pas diferent.

Això es reflecteix amb una tendència comuna a moltes societats europees i té una repercussió molt greu en l'entorn educatiu, un cop que les mateixes investigacions assenyalen que hi ha un jerarquia compartida en moltes societats europees que situen els nord-europeus al cap de llista, seguits pels europeus del est i del sud, els americans del sud i del centre, els asiàtics i els africans, al final de la llista (Snellman i Ekehammar, 2005: 83-94; Hagendoorn i altres, 1998: IV, 483-503). La preocupació que aquesta «llista» genera és que els grups d'aquesta, que estan posicionats com els més allunyats de «l'ideal» europeu, són justament els més nombrosos. Però algunes investigacions (Rodríguez i altres, 2006: I, 73-77; Rodríguez-Bailón i Moya-Morales, 2003: II,176-182; Rueda i Navas, 1996: III, 131-149; Matera i altres, 2005: I, 83-92) indiquen que els gitanos són vistos com encara més allunyats d'aquest ideal cultural europeu contemporani. Evidentment, hi ha grups i grups, i la jerarquia o la distància entre els diferents pot ser molt diversa.

Hi ha grups que estan menys «protegits» del prejudici o, almenys, de la seva manifestació explícita. Si comparem dos «pobles de diàspora»-que no tenen un 'per a on' tornar- per exemple, s'observa que els jueus són molt més protegits de manifestacions explícites de prejudici o discriminació que els gitanos, que encara avui s'apropen als mateixos nivells d'infra-humanització d'abans de la Segona Guerra Mundial (Dambrun i Guimond, 2004: 663-676).

L'educació, considerant les relacions interètniques, s'ha d'encarar com un procés sistemàtic. Es tracta d'un procés que ve marcat pel ritme dels canvis esdevinguts en la convivència, en el dia a dia, en l'ambient de companys i la igualtat, on hi ha exposició, interpretació de significats, ressignificació d'idees, projectes, postures i valors. Ha de ser una experiència deliberadament elaborada per tots els participants, que parteixen 
d'un objectiu expressat conjuntament que, en aquesta situació, és el de combatre les discriminacions i el racisme (Silva, 1998: 381-398). No sempre l'avaluació política o els discursos de fa 30 anys poden servir per a fer front a la realitat d'avui.

Tota aquesta discussió té encara més sentit si es pensa en quan (i com) aquesta temàtica guanya espai als medis informatius. Cal entendre millor els fenòmens d'encontre i desencontre cultural, així com les implicacions en els processos identitaris (OSPDH, 2006). El discurs social té grups d'actors molt diferents i amb implicacions directes molt diferenciades quant a la influència en el marc educatiu. Un segment social clau és el dels educadors; directament implicats en els processos de multiculturalitat a l'escola. Si es considera que els mestres i educadors s'apropen més al discurs social negatiu cara a la multiculturalitat i no al discurs acadèmic marcat per una forta defensa de la diversitat cultural. Els educadors són peces clau per a una educació de qualitat i, en el cas de l'educació intercultural, això no és pas diferent (Jordán, 2002: 65-74).

Tot $\mathrm{i}$ això, hi ha escoles $\mathrm{i}$ professors amb una concepció clara de la multi o interculturalitat, que realitzen un treball equilibrat, compromès, on harmonitzen la visió pràctica, equitativa i raonablement universalista (Jordán, 2002: 65-74). La perspectiva de Jordán (2002: 65-74) justifica aquestes postures entenent que la multiculturalitat social i escolar no és un "problema» per se; però sí que es pot viure com a tal, amb símptomes d'ansietat i d'impotència professional per part de professors que se senten sols, poc formats i sense ajuda cara a una realitat nova i temorosa. El problema es presenta, evidentment, amb més gravetat quan, a més, aquest nou tipus d'alumnat arriba de manera abundant, amb poca escolarització prèvia, amb difícil comunicació amb les famílies, pertanyents a moltes nacionalitats diferents i, sobretot si es concentra en escoles marginals (Jordán, 2002: 65-74).

\section{L'ús de la llengua com marcador identitari}

Un altre element molt important i, molts cops present en el discurs docent, és l'ús de la llengua en els entorns educatius catalans. La llengua juga diferents rols en la definició i en la formació dels grups ètnics, fins a tal punt que es pot definir la identitat en termes com etnolingüística, tal com proposen Huguet i Lapresta (2004).

Aquest procés, molt intens en determinats entorns, sorgeix de les relacions intergrupals entre els grups etnolingüístics. L'anàlisi que fan Hohl i Normand (2003: 57-68) dels principals elements constituents de la identitat i d'assenyalament de les diferenciacions entre subgrups culturals en societats plurals i dividides (com són el Quebec, Irlanda del Nord, Bèlgica i Catalunya), identifica l'ús de la llengua com el principal marcador identitari català. En aquest sentit, es pot entendre també que el col·lectiu de professors i professores, com a grup social, està associat amb «el treball» de 
construcció de la identitat nacional catalana, que s'efectua intensament a través de les institucions públiques, després del restabliment de la Generalitat de Catalunya, amb la fi del règim franquista (Hohl i Normand, 2003: 57-68).

El concepte de «societat dividida» tracta de caracteritzar els contextos on la identificació d'un grup majoritari clarament dominant és difícil. Una situació semblant pot resultar quan dos o més grups, amb interessos divergents, es troben en una relació de poder pràcticament equivalent, que els fa igualment capaços o incapaços de controlar l'Estat i la definició de la «nació». Una segona variant, que presenta una situació menys conflictiva, almenys mentre un dels grups no tracti de qüestionar l'status quo, sobrevé si aquests grups comparteixen les esferes de poder paral·leles i es reserven els espais geogràfics, institucionals i simbòlics relativament hermètics que minimitzen els contactes interètnics (McAndrew, 2003: 101-117).

A Catalunya, encara que s'imposi un debat més profund, sembla que la situació de diglòssia difosa en l'eix d'una gran majoria de la població contribueix cap a fronteres ètniques més confoses i menys permanents que en altres contextos d'ambigüitat de domini ètnic, tal com passa a Irlanda del Nord, Bèlgica i el Quebec (McAndrew, 2003: 101-117).

En realitat, el context català podria ser caracteritzat més com una societat amb ambigüitat de predomini lingüístic, perquè no oposa sempre grups clarament definits en termes ètnics. Tot i així, la identitat dels grups en competició és molt marcada per l'ús de la llengua, que té un paper fonamental en el cas català. Segons McAndrew (2003: 101-117), els catalans d'identitat catalano parlant actualment són demogràficament minoritaris, encara que dominants en el terreny econòmic.

A Catalunya hi ha un sistema escolar relativament unificat on castellanoparlants $i$ catalanoparlants coneixen un espai de socialització comú. Això, evidentment, sense considerar aquí el fenomen creixent de sorgiment de escoles gueto en la realitat actual (McAndrew, 2003: 101-117). La societat catalana, així com algunes esferes de la seva funció pública, estan travessades per definicions diferents, fins i tot, conflictives de la identitat catalana i dels pobles o comunitat, que formen aquesta «nació» i, l'ús de la llengua sembla ser un dels pocs marcadors acordats, almenys dins del grup cultural majoritari (Hohl i Normand, 2003: 57-68).

L'atracció que manifesten els immigrants i, sobretot, la minoria gitana per l'univers castellanoparlant, provoca un sentiment de fragilitat pel que fa al manteniment i al desenvolupament de la capacitat d'afirmació d'una Catalunya catalana. Per raons com aquesta «amenaça» resulta molt difícil per al grup de catalans d'etnicitat catalana catalanoparlant (el grup políticament majoritari) assumir un estatus doble i contradictori de grup dominant i dominat. Dominant en relació amb aquests grups minoritaris, que no tenen les mateixes possibilitats de ciutadania plena i dominats (fins $i$ tot moltes vegades de manera exageradament victimitzada) per un context major espanyol, castellanoparlant. 
Les provisions escolars de la Llei de normalització lingüística catalana tracten de modificar la dinàmica sociolingüística existent, amb l'augment de l'estatuts del català com a llengua d'ensenyança i comunicació (McAndrew, 2003: 101-117). Totes les temptatives d'utilitzar l'escola amb fins de modificació de les relacions ètniques tenen, sens dubte, un punt en comú: la tendència a donar lloc, quant a la seva pertinència o als seus resultats, a preses de posició basades, sobretot, en les orientacions normatives o ideològiques del seus partidaris o detractors, igual que a una avaluació rigorosa de les seves conseqüències positives i efectes perversos.

\section{Consideracions finals}

S’ha de reflexionar sobre la relació que hi ha entre la línia política, marcada pel Departament d'Educació de la Generalitat de Catalunya, i la pràctica pedagògica quant a l'ús de la llengua catalana i de la resta de llengües que es troben actualment a les escoles del territori català.

En les pràctiques actuals, amb fortes tendències assimilacionistes en determinats aspectes, com en el cas de l'ús de la llengua, es valoren les situacions educatives en relació amb una perspectiva política (identificada amb determinats valors i discursos ja comentats) i no pedagògica, o psicològica.

Així, la panoràmica no és tan simple com a vegades els mitjans de comunicació volen presentar. Hi ha també molts elements que configuren el discurs i les pràctiques socials, sigui a l'escola o a la vida comunitària. Les relacions establertes amb les persones identificables amb el rètol de «diversitat» necessiten una avaluació també a un nivell microanalític, situacional i específic per a cada situació, tal i com proposa la pròpia definició del tema.

\section{Bibliografia}

Berry, J. W. (2001): «A Psychology of Immigration», Journal of Social Issues, 57.

CARrasco, S. (coord.). (2004a): Inmigración, contexto familiar y educación, Serie Sociedad y Educación, Barcelona.

-(2004b): Infancia e inmigración: proyectos y realidades. En GómEZ-GranELL, C., A. García Milà, A. Ripoll-Millet, C. Panchón (2004): Infancia y Familias: realidades y tendencias, Ariel, Barcelona.

Crespo, I. i altres (1994): Derecho a la propia cultura: universalidad de valores o sesgo de la cultura dominante. Infancia y Sociedad, 27/28.

Dambrun, M. i S. Guimond (2004): «Implicit and explicit measures of prejudice and stereotyping: do they assess the same underlying knowledge structure?», European Journal of Social Psychology, 34. 
Diputació de Barcelona (2000): Els gitanos de Barcelona, Editora de la Diputació de Barcelona, Barcelona.

Essomba, M. A. (2002): Los objetivos de la educación intercultural. Aspectos diferenciales de su función y naturaleza. En: Essomba, M. A. (coord.) (2002): Construir la escuela intercultural: reflexiones y propuestas para trabajar la diversidad étnica y cultural, Graó, Barcelona.

Essomba, M.A. (coord.) (2003): Educación e inclusión social de los inmigrados y minorías. Tejer redes de sentido compartido, Praxis, Barcelona.

FERnÁndez-Enguita, M. (1999): Alumnos gitanos en la escuela paya: un estudio sobre las relaciones étnicas en el sistema educativo, Ariel Practicum, Barcelona.

Gadotтi, M. (1993): Diversidade cultural e educação para todos, Graal, Río de Janeiro.

Generalitat de Catalunya - Departament d'Educació (2005): Pla per la llengua i la cohesió social, Generalitat de Catalunya, Barcelona.

Generalitat de Catalunya - Departament de Benestar i Família (2005b): Estudi sobre la població gitana de Catalunya - Informe final, Generalitat de Catalunya, Barcelona.

Greenfield, P. M. i R. Cocking (1994): Cross-cultural Roots of Minority Child development, LEA, Hillsdale.

Hagendoorn, L. i altres (1998): «Inter-ethnic preferences and ethnic hierarchies in the former soviet union», International Journal of Intercultural Relations, 22.

Hohl, J. i M. Normand (2003): Enseñar en medio pluriétnico en una sociedad dividida. In: Garreta, J., SAmper, L. i Llevot, N. (2003): Relaciones étnicas y educación en una sociedad dividida: Québec, Edicions de la Universitat de Lleida, Lleida.

Huguet, J. i M. Lapresta (2004): «El prestigio de las lenguas en los escolares. Influencia de algunas variables educativas y familiares», Revista de Psicologia General y Aplicada, 57(4).

JordÁn, J. A. (1994): La escuela multicultural, Editorial Paidós, Barcelona.

-(2002): El profesorado ante la educación intercultural. En: ESSOMBA, M. A. (coord.) (2002): Construir la escuela intercultural: reflexiones y propuestas para trabajar la diversidad étnica y cultural, Graó, Barcelona.

Lalueza, J. L. i I. CRespo (1996): Algunas dificultades generadas por el sesgo cultural en el estudio del desarrollo humano, Cultura y Educación, 3.

Lubart, T. (2007): Psicologia da criatividade, Artmed, Porto Alegre.

Matera, C. i altres (2005): «Autoestereotyping and nacional identity in the spanish context», Interamerican Journal of Psychology, 39.

MCANDREW, M. (2003): La educación en situaciones de ambigüedad de dominio étnico: Bélgica, Cataluña, Irlanda del Norte y Quebec. In: J. GArreta, L. SAmPer i N. LLEVOT (2003): Relaciones étnicas y educación en una sociedad dividida: Québec, Edicions de la Universitat de Lleida, Lleida.

MCLaren, P. (1995): Multiculturalismo revolucionário: pedagogia do dissenso para o novo milênio, Artmed, Porto Alegre. 
OSPDH - Observatorio del Sistema Penal y Derechos Humanos (2006): Imagen mediática y opinión pública sobre la inmigración en España y Catalunya, Universitat de Barcelona, Barcelona.

Rodríguez, A. i altres (2006): «Amenaza al endogrupo y nivel de infrahumanización del exogrupo», Psicothema, 18.

Rodríguez-Bailón, R. i M. Moya-Morales (2003): «La diferencia percibida en valores como proceso vinculado a las relaciones intergrupales de payos y gitanos», Psicothema, 15.

Rogoff, B. (1993): Aprendices del pensamiento: el desarrollo cognitivo en el contexto social, Paidós, Barcelona.

Rueda, J. F. y M. Navas Luque (1996): «Hacia una evaluación de las nuevas formas del prejuicio racial: las actitudes sutiles del racismo,» Revista de Psicología Social, 11.

Sandín, M. P. (2002). La socialización del alumnado en contextos multiculturales. En: Essomba, M. A. (coord.) (2002): Construir la escuela intercultural: reflexiones y propuestas para trabajar la diversidad étnica y cultural. Graó, Barcelona.

SAn Román, T. (1996): La diferència inquietant. (2 ed.), Alta Fulla, Barcelona.

- $\mathrm{i}$ altres (2001): Identitat, pertinença i primacia a l'escola: La formació d'ensenyament en el camp de les relacions interculturals. Publicacions d'Antropologia Cultural, Universitat Autònoma de Barcelona, Bellaterra.

SILVA, P. (1998): Espaços para educação das relações interétnicas: Contribuições da produção científica e da prática docente, entre gaúchos, sobre negro e educação. In: Silva, L. (ed.). A escola cidadã no contexto da globalização, Vozes, Petrópolis.

Snellman, A. i B. Ekehammar (2005): «Ethnic hierarchies, ethnic prejudice, and social dominance orientation», Journal of Community \& Applied Social Psychology, 15.

Woolfolk, A. (2000): Psicologia da educação, Artes Médicas, Porto Alegre. 